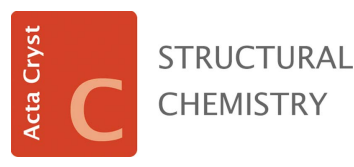

ISSN 2053-2296

Received 25 February 2016

Accepted 21 November 2016

Edited by B. D. Santarsiero, University of Illinois at Chicago, USA

${ }^{1}$ This paper is dedicated to Professor S.

Chandrasekaran.

Keywords: myo-inositol; geometry optimization; crystal structure; Hirshfeld surface analysis; lattice energy; transmembrane signalling; potential chemotherapeutic agent.

CCDC reference: 1518275

Supporting information: this article has supporting information at journals.iucr.org/c

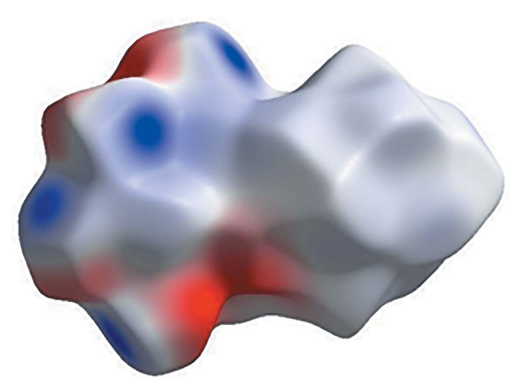

(C) 2017 International Union of Crystallography

\section{Water-mediated intermolecular interactions in 1,2-O-cyclohexylidene-myo-inositol: a quantitative analysis ${ }^{1}$}

\author{
Gayathri Purushothaman, ${ }^{\text {a }}$ Kapil Juvale, ${ }^{\mathrm{b}}$ Sivapriya Kirubakaran, ${ }^{\mathrm{a}}$ Praveen Kumar \\ Vemula $^{\mathrm{c}}$ and Vijay Thiruvenkatam ${ }^{\mathrm{a} *}$
}

a Discipline of Biological Engineering, Indian Institute of Technology Gandhinagar, Palaj Campus, Gandhinagar 382355 , Gujarat, India, ${ }^{\mathbf{b}}$ Discipline of Chemistry, Indian Institute of Technology Gandhinagar, Palaj Campus, Gandhinagar 382 355, Gujarat, India, and 'Institute for Stem Cell Biology and Regenerative Medicine (inStem), UAS-GKVK Campus, Bellary Road, Bangalore 560 065, India. *Correspondence e-mail: vijay@iitgn.ac.in

The syntheses of new myo-inositol derivatives have received much attention due to their important biological activities. 1,2-O-Cyclohexylidene-myo-inositol is an important intermediate formed during the syntheses of certain myo-inositol derivatives. We report herein the crystal structure of 1,2-O-cyclohexylidenemyo-inositol dihydrate, $\mathrm{C}_{12} \mathrm{H}_{20} \mathrm{O}_{6} \cdot 2 \mathrm{H}_{2} \mathrm{O}$, which is an intermediate formed during the syntheses of myo-inositol phosphate derivatives, to demonstrate the participation of water molecules and hydroxy groups in the formation of several intermolecular $\mathrm{O}-\mathrm{H} \cdots \mathrm{O}$ interactions, and to determine a low-energy conformation. The title myo-inositol derivative crystallizes with two water molecules in the asymmetric unit in the space group $C 2 / c$, with $Z=8$. The water molecules facilitate the formation of an extensive $\mathrm{O}-\mathrm{H} \cdots \mathrm{O}$ hydrogen-bonding network that assists in the formation of a dense crystal packing. Furthermore, geometrical optimization and frequency analysis was carried out using density functional theory (DFT) calculations with B3LYP hybrid functionals and 6$31 \mathrm{G}(\mathrm{d}), 6-31 \mathrm{G}(\mathrm{d}, \mathrm{p})$ and $6-311 \mathrm{G}(\mathrm{d}, \mathrm{p})$ basis sets. The theoretical and experimental structures were found to be very similar, with only slight deviations. The intermolecular interactions were quantitatively analysed using Hirshfeld surface analysis and 2D (two-dimensional) fingerplot plots, and the total lattice energy was calculated.

\section{Introduction}

In recent decades, the syntheses of new myo-inositol derivatives have received much attention due to their important biological activities. Myo-inostiol mono- and polyphosphates act as important secondary messengers in transmembrane signalling and are currently being investigated as potential chemotherapeutic agents. Inositol derivatives are important in cellular signaling via protein kinases in endocytosis and exocytosis, and in the vesicular trafficking of proteins (Berridge \& Irvine, 1989; De Camilli et al., 1996; Schekman \& Orci, 1996). Different myo-inositol phosphate derivatives have been reported to possess the ability to inhibit cancer growth (Baten et al., 1989; Shamsuddin, 1995; Yang \& Shamsuddin, 1995; Vucenik \& Shamsuddin, 2003; Chen et al., 2015). 1,2-O-Cyclohexylidene-myo-inositol, (1), is an important intermediate formed during the syntheses of certain myoinositol derivatives. We report herein the crystal structure of the dihydrate of (1), denoted (I) $2 \mathrm{H}_{2} \mathrm{O}$, to demonstrate the participation of water molecules and hydroxy groups in the formation of several intermolecular $\mathrm{O}-\mathrm{H} \cdots \mathrm{O}$ interactions, and to determine a low-energy conformation. 
1,2-O-Cyclohexylidene-myo-inositol was synthesized from myo-inositol by reacting it with 1,1-dimethoxycyclohexane in the presence of $p$-toluenesulfonic acid (see Scheme 1).<smiles>O[C@H]1[C@H](O)[C@@H](O)[C@H](O)[C@@H](O)[C@H]1O</smiles>

myo-inositol

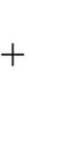<smiles>COC1(OC)CCCCC1</smiles>

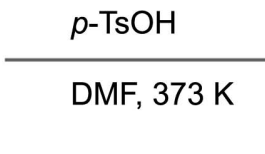

\section{1,1-dimethoxycyclohexane}<smiles>OC1C(O)C2OC3(CC[CH+]CC3)OC2C1O</smiles>

(1) $(29 \%)$

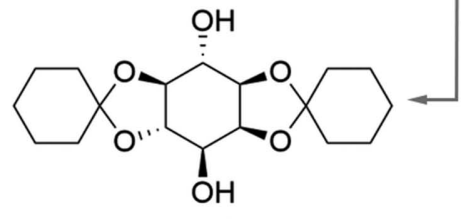

(2) $(5.5 \%)$

\section{Scheme 1}

The packing of molecules in the crystal structure depends on the type of bonding present between the molecules (Kaftory et al., 1994). The most prominent bonding present is $\mathrm{O}-\mathrm{H} \cdots \mathrm{O}$ hydrogen bonding and these bonds are highly directional (Desiraju, 1999) and are consistently present in the variety of bonding interactions reported for organic molecules. These interactions play a distinct role in determining the stability and existence of an assembly of molecules, and can be as important as covalent bonds (Kaftory et al., 1994). We have determined the optimized structure parameters of (1) using density functional theory (DFT) to calculate the groundstate geometries (Parr, 1989). The geometric optimization and frequency analysis was carried out using the GAUSSIAN09 software package (Frisch et al., 2009). The calculated structures are compared with the experimental structure.

The characterization and quantification of the intermolecular interactions in (1) $\cdot 2 \mathrm{H}_{2} \mathrm{O}$ was carried out by Hirshfeld surface analysis and 2D (two-dimensional) fingerprint plots using the Crystal Explorer program (Spackman \& Jayatilaka, 2009; Wolff et al., 2012; Spackman \& McKinnon, 2002; McKinnon et al., 2004). The Hirshfeld surface was mapped with $d_{\mathrm{e}}, d_{\text {norm }}$, the shape index and the curvedness, which helps to visualize the intermolecular interactions and the crystal packing (González-Montiel et al., 2015). The 2D fingerprint plots give a measurement of the different intermolecular interactions (Spackman \& McKinnon, 2002). The total lattice energy was calculated using the PIXELC program, which helps in the understanding of the crystal stability by studying the total interaction energy as a contribution of different interaction energies (Gavezzotti, 2011).

\section{Experimental}

The monoacetal derivative of myo-inositol (see Scheme 1) was synthesized by reacting myo-inositol with 1,1-dimethoxycyclohexane in the presence of $p$-toluenesulfonic acid. All the chemicals used were purchased from Sigma-Aldrich or Alfa Aesar. The progress of the reaction was monitored using analytical thin-layer chromatography (TLC) on silica-gel plates (Silica Gel 60 F254 from Merck). Compound (1) $\cdot 2 \mathrm{H}_{2} \mathrm{O}$ was characterized by an analysis of the NMR spectra, which were recorded in DMSO- $d_{6} .{ }^{1} \mathrm{H}$ NMR spectra were obtained on a Bruker Avance $500(500 \mathrm{MHz})$ and ${ }^{13} \mathrm{C}$ NMR spectra were obtained on a Bruker Avance $500(126 \mathrm{MHz})$; chemical shifts are expressed in $\delta(\mathrm{ppm})$ using the solvent peak as an internal standard. The multiplicity of the resonance peaks is indicated as singlet $(s)$, doublet $(d)$, triplet $(t)$, quartet $(q)$ or multiplet $(m)$. The ${ }^{13} \mathrm{C}$ signals were assigned with the aid of the attached proton test (APT) and the $J$ values are in Hertz.

2.1. Synthesis and crystallization of cyclohexylidene derivatives of myo-inositol

1,2-O-Cyclohexylidene-myo-inositol, (1), was synthesized from myo-inositol by the addition of 1,1-dimethoxycyclohexane in the presence of $p$-toluenesulfonic acid (see Scheme 1), according to a previously reported procedure with small modifications (Suzuki et al., 2002). To a solution of myoinositol $(1 \mathrm{~g}, 5.56 \mathrm{mmol})$ in dimethylformamide was added $p$-toluenesulfonic acid $(0.16 \mathrm{mmol})$. To the resulting solution, 1,1-dimethoxycyclohexane $(2.5 \mathrm{ml}, 16.6 \mathrm{mmol})$, prepared as described previously (Roy et al., 2009), was added. The reaction mixture was stirred at $373 \mathrm{~K}$ for $12-14 \mathrm{~h}$. After completion of the reaction, as indicated by TLC analysis, the reaction mixture was cooled to room temperature and triethylamine ( $772 \mu \mathrm{l}, 0.54 \mathrm{mmol}$ ) was added. Excess 1,1-dimethoxycyclohexane was removed under reduced pressure. To the resultant residue, dichloromethane $(50 \mathrm{ml})$ was added and the solution kept at $277 \mathrm{~K}$ for 3-4 h. The precipitate was filtered off and washed with dichloromethane to remove any nonpolar side products, giving 1,2- $O$-cyclohexylidene-myo-inositol, (1), as a white solid [yield $421 \mathrm{mg}$, 29\%; m.p. $454 \mathrm{~K}$, uncorrected m.p. 452-454 K (Nkambule et al., 2011; Guthrie \& Johnson, 1961; Jiang \& Baker, 1986)]. ${ }^{1} \mathrm{H}$ NMR (500 MHz, DMSO- $\left.d_{6}\right): \delta 5.00$ $\left(d, J=2.7 \mathrm{~Hz}, 1 \mathrm{H}, \mathrm{D}_{2} \mathrm{O}\right.$ exchangeable $), 4.91(d, J=4.9 \mathrm{~Hz}, 1 \mathrm{H}$, $\mathrm{D}_{2} \mathrm{O}$ exchangeable $), 4.86\left(d, J=3.1 \mathrm{~Hz}, 1 \mathrm{H}, \mathrm{D}_{2} \mathrm{O}\right.$ exchangeable), $4.77\left(d, J=4.1 \mathrm{~Hz}, 1 \mathrm{H}, \mathrm{D}_{2} \mathrm{O}\right.$ exchangeable $), 4.16(t, J=$ $4.7,3.7 \mathrm{~Hz}, 2 \mathrm{H}), 3.55-3.44(m, 2 \mathrm{H}), 3.32(d t, J=13.8,8.4 \mathrm{~Hz}$, $2 \mathrm{H}), 2.95-2.88(m, 1 \mathrm{H}), 1.53-1.32(10 \mathrm{H}) ;{ }^{13} \mathrm{C}$ NMR $(126 \mathrm{MHz}$, DMSO): $\delta 108.99,79.25,76.48,75.50,74.64,72.71,70.38,55.37$, $40.48,40.32,40.15,39.98,39.82$, 39.65, 39.48, 38.11, 35.40, 25.11, 24.11, 23.79.

Slow evaporation of a solution of the synthesized (1) from methanol at $277 \mathrm{~K}$ produced colourless block-shaped crystals suitable for single-crystal X-ray diffraction analysis.

\subsection{Data collection and refinement}

Single-crystal X-ray diffraction data were collected on a Bruker SMART APEXII CCD diffractometer using an Mo $K \alpha$ $(\lambda=0.7107 \AA)$ source at $298 \mathrm{~K}$, and the intensities were measured using $\omega$ scans with a scan width of $0.3^{\circ}$. A total of 100 frames per set were collected in multiple settings of $\phi(\phi=$ 0,90 and $180^{\circ}$ when the system is monoclinic, or $\phi=0,90,180$ and $270^{\circ}$ when it is triclinic) and keeping a sample-to-detector

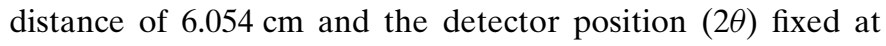


$-25^{\circ}$. Crystal data, data collection and structure refinement details are summarized in Table 1 . The hydroxy $\mathrm{H}$ atoms were fixed with $\mathrm{O}-\mathrm{H}$ distances of $0.84 \AA$. All other $\mathrm{H}$ atoms were refined freely.

\subsection{Geometry optimization and frequency analysis of (1)}

To obtain the optimized structure of (1), quantum-chemical calculations were performed using Becke's three-parameter exchange function (B3) with the Lee-Yang-Parr correlation function (LYP) and three different basis sets, i.e. 6-31G(d), 6-31G(d,p) and 6-311G(d,p) (Becke, 1993). Geometry optimizations of (1) were carried out in the gas phase at the DFT level of theory using B3LYP without any symmetry restrictions, and all of the optimized geometries were confirmed by frequency analyses at the same level of theory as explained by Tokay et al. (2008). Geometry optimization and frequency calculations were carried out using the GAUSSIAN09 package (Frisch et al., 2009). The overlay and r.m.s. deviation calculations using the experimental and calculated structures of (1) were performed using CHEMCRAFT (http://www. chemcraftprog.com).

\subsection{Intermolecular interactions by Hirshfeld surface analysis and 2D fingerprint plots}

The intermolecular interactions in (1) were quantified by Hirshfeld surface (HS) and fingerprint plot analysis using the Crystal Explorer software package (Wolff et al., 2012) using the CIF file directly. The Hirshfeld surfaces were mapped with $d_{\text {norm }}$, shape index and curvedness, and the distribution of electron densities and the intermolecular interactions in the crystal packing were explored (Spackman \& Jayatilaka, 2009). The overall intermolecular interactions contributed by individual interactions (i.e. $\mathrm{H} \cdots \mathrm{H}, \mathrm{O} \cdots \mathrm{H}, \mathrm{O} \cdots \mathrm{O}$ and $\mathrm{H} \cdots \mathrm{H}$ ) were estimated using 2D fingerplot plots (Spackman \& McKinnon, 2002). Also, in order to visualize the electrostatic complementarities in the crystal packing, the electrostatic potentials were mapped onto the HS surface using the STO$3 \mathrm{G}$ basis set for the DFT calculations and the crystal coordi-

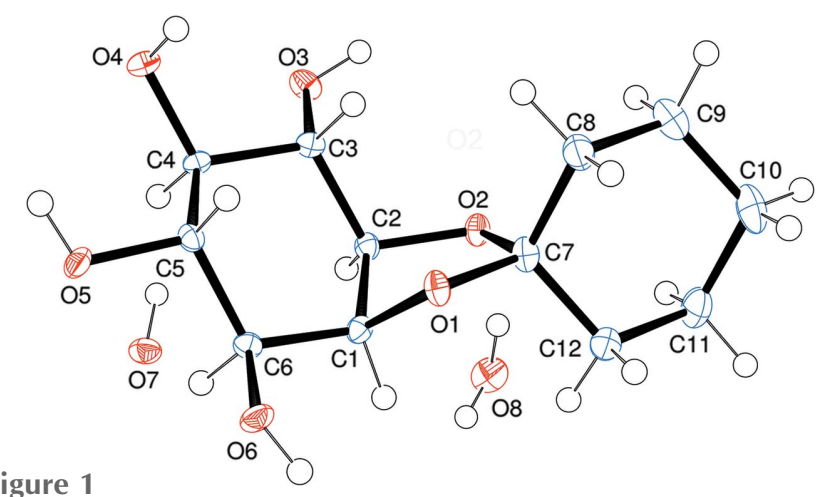

Figure 1

A view of the title compound, (1) $\cdot 2 \mathrm{H}_{2} \mathrm{O}$, showing the atom-numbering scheme. Displacement ellipsoids for non-H atoms are drawn at the $50 \%$ probability level. Note that the second $\mathrm{H}$ atom on water atom $\mathrm{O} 7$ was not located and has not been included in the picture or the refinement model.
Table 1

Experimental details.

\begin{tabular}{|c|c|}
\hline \multicolumn{2}{|l|}{ Crystal data } \\
\hline Chemical formula & $\mathrm{C}_{12} \mathrm{H}_{20} \mathrm{O}_{6} \cdot 2 \mathrm{H}_{2} \mathrm{O}$ \\
\hline$M_{\mathrm{r}}$ & 296.31 \\
\hline Crystal system, space group & Monoclinic, $C 2 / c$ \\
\hline Temperature (K) & 298 \\
\hline$a, b, c(\AA)$ & $38.459(3), 8.6208(7), 8.2420(7)$ \\
\hline$\beta\left(^{\circ}\right)$ & $95.371(2)$ \\
\hline$V\left(\AA^{3}\right)$ & $2720.6(4)$ \\
\hline$Z$ & 8 \\
\hline Radiation type & Mo $K \alpha$ \\
\hline$\mu\left(\mathrm{mm}^{-1}\right)$ & 0.12 \\
\hline Crystal size $(\mathrm{mm})$ & $0.45 \times 0.35 \times 0.35$ \\
\hline \multicolumn{2}{|l|}{ Data collection } \\
\hline Diffractometer & Bruker APEXII CCD \\
\hline Absorption correction & $\begin{array}{l}\text { Multi-scan (SADABS; Bruker, } \\
\text { 2008) }\end{array}$ \\
\hline$T_{\min }, T_{\max }$ & $0.935,0.972$ \\
\hline $\begin{array}{l}\text { No. of measured, independent and } \\
\text { observed }[I>2 \sigma(I)] \text { reflections }\end{array}$ & $38263,3391,2347$ \\
\hline$R_{\mathrm{int}}$ & 0.129 \\
\hline$(\sin \theta / \lambda)_{\max }\left(\AA^{-1}\right)$ & 0.668 \\
\hline \multicolumn{2}{|l|}{ Refinement } \\
\hline$R\left[F^{2}>2 \sigma\left(F^{2}\right)\right], w R\left(F^{2}\right), S$ & $0.055,0.140,1.24$ \\
\hline No. of reflections & 3391 \\
\hline No. of parameters & 261 \\
\hline No. of restraints & 1 \\
\hline $\mathrm{H}$-atom treatment & $\begin{array}{l}\mathrm{H} \text { atoms treated by a mixture of } \\
\text { independent and constrained } \\
\text { refinement }\end{array}$ \\
\hline$\Delta \rho_{\max }, \Delta \rho_{\min }\left(\mathrm{e} \AA^{-3}\right)$ & $0.20,-0.21$ \\
\hline
\end{tabular}

Computer programs: APEX2 (Bruker, 2009), SAINT-Plus (Bruker, 2012), SHELXL97 (Sheldrick, 2008) in WinGX (Farrugia, 2012), ORTEP-3 for Windows (Farrugia, 2012), CAMERON (Watkin \& Prout, 1993), Mercury (Macrae et al., 2008) and PLATON (Spek, 2009).

nates as the input into the TONTO package (Jayatilaka et al., 2005) integrated with Crystal Explorer.

\subsection{Lattice energy calculations for (1)}

The lattice energy of (1) was calculated using the PIXELC module in the CLP (Coulomb-London-Pauli) package (Version 3.0 of November 2015; Gavezzotti, 2011; Elahi \& Kant, 2014) using the atomic coordinates from the CIF file.

\section{Results and discussion}

3.1. Synthesis and crystal structure of cyclohexylidene derivatives of myo-inositol

The title compound, (1) $\cdot 2 \mathrm{H}_{2} \mathrm{O}$, was synthesized from myoinositol using 1,1-dimethoxycyclohexane in the presence of $p$-toluenesulfonic acid. 1,2-O-Cyclohexylidene-myo-inositol was formed as the major product in $29 \%$ yield. 1,$2 ; 4,5-\mathrm{Di}-O$ cyclohexylidene-myo-inositol, (2), was recovered in a very low yield of $5.5 \%$. This may be due to the trans configuration of the hydroxy groups present at positions 4 and 5 of the myoinositol skeleton and difficulties in the formation of the acetal intermediate.

The crystal structure of (1) $\cdot 2 \mathrm{H}_{2} \mathrm{O}$ shows the presence of trans hydroxy groups at positions 4 and 5 of the myo-inositol skeleton (Fig. 1), and gives complete details of the confor- 


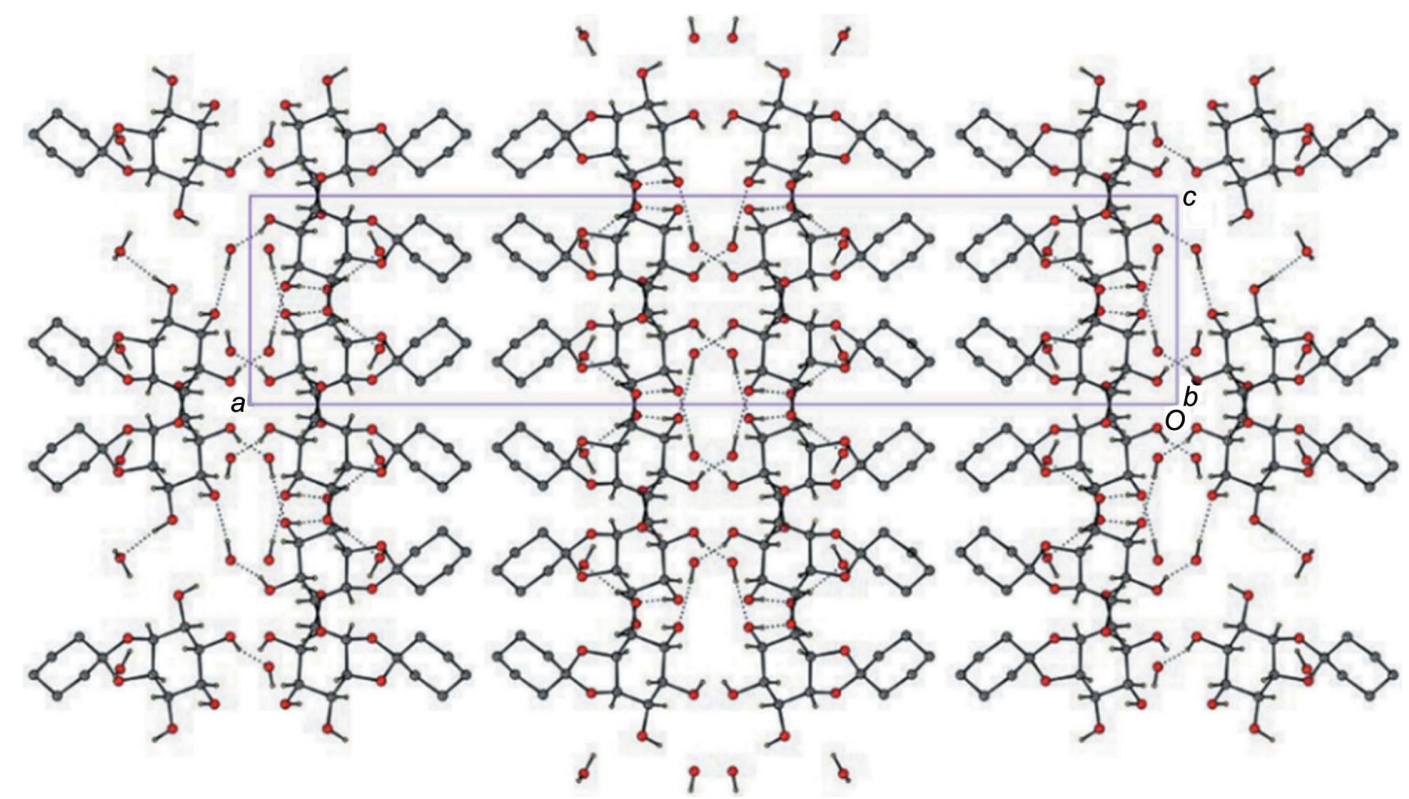

Figure 2

The network of intermolecular hydrogen bonding in myo-inositol derivative (1) $2 \mathrm{H}_{2} \mathrm{O}$.

mation of the molecule. It is clearly identifiable that the hydroxy groups $(3,4,5,6-\mathrm{OH})$ of the inositol unit are in equatorial positions and atom $\mathrm{O} 1$ attached to the cyclohexylidene ring is in an axial position. The $\mathrm{C} 4-\mathrm{C} 3-\mathrm{C} 2-\mathrm{O} 2$ torsion angle of $-161.70(14)^{\circ}$ demonstrates that the atoms are very nearly planar, whereas the $\mathrm{C} 5-\mathrm{C} 6-\mathrm{C} 1-\mathrm{O} 1$ torsion angle of $68.50(18)^{\circ}$ demonstrates that the atoms are nonplanar. Tables 1 and 2 list the relevant crystallographic data and intermolecular interactions of (1) and Table 3 lists the torsion angles for the assignment of equatorial and axial configurations. The network of $\mathrm{O}-\mathrm{H} \cdots \mathrm{O}$ interactions can be seen in the packing diagram (Fig. 2). Here, the two water molecules are involved in bifurcated intermolecular $\mathrm{O}-\mathrm{H} \cdots \mathrm{O}$ hydrogen bonding, as shown in Fig. 3, which stabilizes the extended crystal packing.

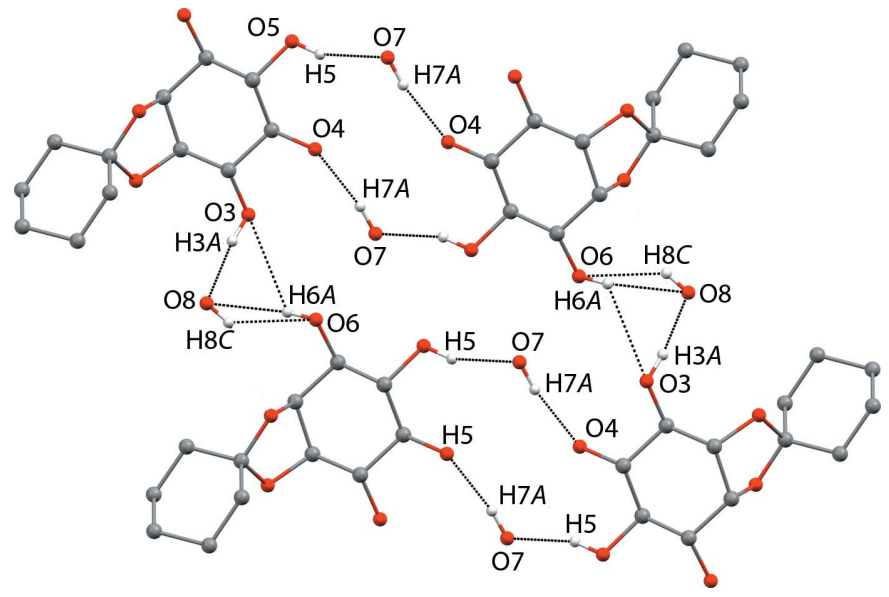

Figure 3

Interactions driven specifically by the water molecules with myo-inositol derivative (1) $2 \mathrm{H}_{2} \mathrm{O}$. Generic atom labels without symmetry codes have been used.
The structure determination of (1) allows for the analysis of conformational features of both the equatorial and axial configurations in the hydrated form of (1). This provides useful insights into the design aspects of anticancer agents.

\subsection{Cambridge Structural Database (CSD) analysis}

A CSD (Version 5.36, update of November 2014, and Web CSD Version 5.36, update of February 2015; Groom \& Allen, 2014; Allen, 2002; Allen \& Motherwell, 2002) search for the myo-inositol framework yielded ten substructures highlighting the inositol moiety. It is very interesting to see that most substructures, i.e. nine, are found in the anhydrous form; the remaining structure is myo-inositol-1,2-camphor acetal trihydrate (Gainsford et al., 2007). The CSD similar-structure search for (1) gave 1320 hits with a minimum similarity coefficient (MSC) cut-off of 0.7. These included 47 structures having the inositol scaffold with an MSC cut-off of 0.974 to 0.900 , and 893 similar structures with an MSC cut-off of 0.897 to 0.80 , followed by 378 structures with an MSC cut-off of 0.798 to 0.70 . The MSC lies between 0 and 1 , and a value near 1 suggests a similar structure based on the structural features,

Table 2

Hydrogen-bond geometry $\left(\AA{ }^{\circ}\right)$.

\begin{tabular}{|c|c|c|c|c|}
\hline$D-\mathrm{H} \cdots A$ & $D-\mathrm{H}$ & $\mathrm{H} \cdots A$ & $D \cdots A$ & $D-\mathrm{H} \cdots A$ \\
\hline $\mathrm{O} 3-\mathrm{H} 3 A \cdots \mathrm{O} 8^{\mathrm{i}}$ & 0.84 & 1.89 & $2.724(2)$ & 170 \\
\hline $\mathrm{O} 4-\mathrm{H} 4 A \cdots \mathrm{O} 3^{\mathrm{i}}$ & 0.84 & 1.91 & $2.754(2)$ & 177 \\
\hline $\mathrm{O} 5-\mathrm{H} 5 \cdots \mathrm{O} 4$ & 0.84 & 2.46 & $2.853(2)$ & 109 \\
\hline $\mathrm{O} 5-\mathrm{H} 5 \cdots \mathrm{O} 7^{\mathrm{ii}}$ & 0.84 & 1.98 & $2.776(2)$ & 158 \\
\hline $\mathrm{O} 6-\mathrm{H} 6 A \cdots \mathrm{O} 8^{\mathrm{iii}}$ & 0.84 & 2.30 & $2.914(2)$ & 130 \\
\hline $\mathrm{O} 7-\mathrm{H} 7 A \cdots \mathrm{O} 4^{\mathrm{iv}}$ & $0.843(18)$ & $1.944(18)$ & $2.779(2)$ & $171(3)$ \\
\hline $\mathrm{O} 8-\mathrm{H} 8 C \cdots \mathrm{O}^{\mathrm{v}}$ & $0.76(3)$ & $2.31(3)$ & $2.914(2)$ & $137(3)$ \\
\hline $\mathrm{O} 8-\mathrm{H} 8 D \cdots \mathrm{O} 2$ & $0.91(3)$ & $2.08(3)$ & $2.950(3)$ & $161(3)$ \\
\hline
\end{tabular}

Symmetry codes: (i) $x,-y+1, z+\frac{1}{2}$; (ii) $-x, y,-z+\frac{3}{2}$; (iii) $x,-y, z+\frac{1}{2}$; (iv) $x,-y+1, z-\frac{1}{2}$; (v) $x,-y, z-\frac{1}{2}$. 
Table 3

Selected torsion angles $\left(^{\circ}\right)$.

\begin{tabular}{lclr}
\hline $\mathrm{C} 7-\mathrm{O} 1-\mathrm{C} 1-\mathrm{C} 2$ & $-43.11(16)$ & $\mathrm{C} 2-\mathrm{C} 3-\mathrm{C} 4-\mathrm{C} 5$ & $55.05(18)$ \\
$\mathrm{C} 7-\mathrm{O} 1-\mathrm{C} 1-\mathrm{C} 6$ & $-166.48(14)$ & $\mathrm{C} 2-\mathrm{C} 3-\mathrm{C} 4-\mathrm{O} 4$ & $177.68(14)$ \\
$\mathrm{C} 1-\mathrm{O} 1-\mathrm{C} 7-\mathrm{C} 12$ & $-91.05(17)$ & $\mathrm{O} 3-\mathrm{C} 3-\mathrm{C} 4-\mathrm{O} 4$ & $-60.68(17)$ \\
$\mathrm{C} 1-\mathrm{O} 1-\mathrm{C} 7-\mathrm{O} 2$ & $26.96(16)$ & $\mathrm{O} 3-\mathrm{C} 3-\mathrm{C} 4-\mathrm{C} 5$ & $176.70(13)$ \\
$\mathrm{C} 1-\mathrm{O} 1-\mathrm{C} 7-\mathrm{C} 8$ & $144.73(16)$ & $\mathrm{O} 4-\mathrm{C} 4-\mathrm{C} 5-\mathrm{O} 5$ & $60.37(18)$ \\
$\mathrm{C} 2-\mathrm{O} 2-\mathrm{C} 7-\mathrm{C} 12$ & $120.33(16)$ & $\mathrm{C} 3-\mathrm{C} 4-\mathrm{C} 5-\mathrm{C} 6$ & $-56.44(19)$ \\
$\mathrm{C} 7-\mathrm{O} 2-\mathrm{C} 2-\mathrm{C} 1$ & $-26.72(16)$ & $\mathrm{O} 4-\mathrm{C} 4-\mathrm{C} 5-\mathrm{C} 6$ & $179.93(15)$ \\
$\mathrm{C} 7-\mathrm{O} 2-\mathrm{C} 2-\mathrm{C} 3$ & $93.59(15)$ & $\mathrm{C} 3-\mathrm{C} 4-\mathrm{C} 5-\mathrm{O} 5$ & $-176.00(13)$ \\
$\mathrm{C} 2-\mathrm{O} 2-\mathrm{C} 7-\mathrm{O} 1$ & $0.95(17)$ & $\mathrm{C} 4-\mathrm{C} 5-\mathrm{C} 6-\mathrm{C} 1$ & $51.3(2)$ \\
$\mathrm{C} 2-\mathrm{O} 2-\mathrm{C} 7-\mathrm{C} 8$ & $-116.94(16)$ & $\mathrm{O} 5-\mathrm{C} 5-\mathrm{C} 6-\mathrm{O} 6$ & $-65.51(18)$ \\
$\mathrm{C} 6-\mathrm{C} 1-\mathrm{C} 2-\mathrm{C} 3$ & $44.6(2)$ & $\mathrm{O} 5-\mathrm{C} 5-\mathrm{C} 6-\mathrm{C} 1$ & $173.16(14)$ \\
$\mathrm{C} 6-\mathrm{C} 1-\mathrm{C} 2-\mathrm{O} 2$ & $162.97(14)$ & $\mathrm{C} 4-\mathrm{C} 5-\mathrm{C} 6-\mathrm{O} 6$ & $172.60(15)$ \\
$\mathrm{C} 2-\mathrm{C} 1-\mathrm{C} 6-\mathrm{O} 6$ & $-169.97(14)$ & $\mathrm{O} 1-\mathrm{C} 7-\mathrm{C} 8-\mathrm{C} 9$ & $178.85(17)$ \\
$\mathrm{O} 1-\mathrm{C} 1-\mathrm{C} 6-\mathrm{O} 6$ & $-55.56(18)$ & $\mathrm{O} 2-\mathrm{C} 7-\mathrm{C} 8-\mathrm{C} 9$ & $-65.9(2)$ \\
$\mathrm{O} 1-\mathrm{C} 1-\mathrm{C} 6-\mathrm{C} 5$ & $68.50(18)$ & $\mathrm{C} 12-\mathrm{C} 7-\mathrm{C} 8-\mathrm{C} 9$ & $55.1(2)$ \\
$\mathrm{O} 1-\mathrm{C} 1-\mathrm{C} 2-\mathrm{O} 2$ & $42.40(15)$ & $\mathrm{O} 1-\mathrm{C} 7-\mathrm{C} 12-\mathrm{C} 11$ & $-177.88(17)$ \\
$\mathrm{C} 2-\mathrm{C} 1-\mathrm{C} 6-\mathrm{C} 5$ & $-45.9(2)$ & $\mathrm{O} 2-\mathrm{C} 7-\mathrm{C} 12-\mathrm{C} 11$ & $66.3(2)$ \\
$\mathrm{O} 1-\mathrm{C} 1-\mathrm{C} 2-\mathrm{C} 3$ & $-75.94(18)$ & $\mathrm{C} 8-\mathrm{C} 7-\mathrm{C} 12-\mathrm{C} 11$ & $-54.9(2)$ \\
$\mathrm{O} 2-\mathrm{C} 2-\mathrm{C} 3-\mathrm{O} 3$ & $77.97(18)$ & $\mathrm{C} 7-\mathrm{C} 8-\mathrm{C} 9-\mathrm{C} 10$ & $-55.7(3)$ \\
$\mathrm{C} 1-\mathrm{C} 2-\mathrm{C} 3-\mathrm{O} 3$ & $-169.16(15)$ & $\mathrm{C} 8-\mathrm{C} 9-\mathrm{C} 10-\mathrm{C} 11$ & $56.1(3)$ \\
$\mathrm{C} 1-\mathrm{C} 2-\mathrm{C} 3-\mathrm{C} 4$ & $-48.8(2)$ & $\mathrm{C} 9-\mathrm{C} 10-\mathrm{C} 11-\mathrm{C} 12$ & $-55.1(3)$ \\
$\mathrm{O} 2-\mathrm{C} 2-\mathrm{C} 3-\mathrm{C} 4$ & $-161.70(14)$ & $\mathrm{C} 10-\mathrm{C} 11-\mathrm{C} 12-\mathrm{C} 7$ & $54.5(3)$ \\
\hline
\end{tabular}

e.g. bond lengths, bond angles, torsion angles, atom types and crystallographic information.

3.3. Comparison of the single-crystal X-ray diffraction (XRD) and GAUSSIAN09-optimized structures

To compare the experimental structure of (1) with the minimized structure, we performed a geometry optimization and frequency analysis with B3LYP functionals and three different basis sets, namely 6-31G(d), 6-31G(d,p) and 6-311G(d,p), using GAUSSIAN09 (Frisch et al., 2009). A visual comparison of the experimental structure with the calculated structure of (1) is shown in Fig. 4. All three calculations gave minimized structures with low r.m.s. deviations in the range $0.280-0.285$, suggesting high similarities between the experimental and calculated structures of (1). The slight variation between the experimental and calculated structures could be due to hydrogen-bonding interactions, which are present in the crystal structure, as well as to the difference in

Table 4

Comparison of selected experimental and calculated bond lengths (Å) for (1).

\begin{tabular}{lllllllll}
\hline Functional/Basis set & $\mathrm{O} 4-\mathrm{C} 4$ & $\mathrm{C} 4-\mathrm{C} 3$ & $\mathrm{O} 3-\mathrm{C} 3$ & $\mathrm{C} 3-\mathrm{C} 2$ & $\mathrm{C} 2-\mathrm{O} 2$ & $\mathrm{O} 2-\mathrm{C} 7$ & $\mathrm{C} 7-\mathrm{C} 8$ & $\mathrm{C} 8-\mathrm{C} 9$ \\
\hline B3LYP 6-31G $(d)$ & 1.4297 & 1.5217 & 1.4246 & 1.5296 & 1.4433 & 1.4621 & 1.5157 \\
B3LYP 6-31G(d,p) & 1.4297 & 1.5217 & 1.4246 & 1.5296 & 1.4433 & 1.4621 & 1.5157 \\
B3LYP 6-311G(d,p) & 1.4297 & 1.5217 & 1.4246 & 1.5296 & 1.4433 & 1.4621 & 1.5157 \\
SCXRD & 1.425 & 1.523 & 1.426 & 1.529 & 1.442 & 1.463 & 1.517 \\
\hline
\end{tabular}

Table 5

Comparison of selected experimental and calculated bond angles $\left({ }^{\circ}\right)$ for $(1)$.

\begin{tabular}{lllllllll}
\hline Functional/Basis set & $\mathrm{C} 5-\mathrm{O} 4-\mathrm{C} 4$ & $\mathrm{O} 4-\mathrm{C} 4-\mathrm{C} 3$ & $\mathrm{C} 4-\mathrm{C} 3-\mathrm{O} 3$ & $\mathrm{O} 3-\mathrm{C} 3-\mathrm{C} 2$ & $\mathrm{C} 3-\mathrm{C} 2-\mathrm{O} 2$ & $\mathrm{C} 2-\mathrm{O} 2-\mathrm{C} 7$ & $\mathrm{O} 2-\mathrm{C} 7-\mathrm{C} 8$ & $\mathrm{C} 7-\mathrm{C} 8-\mathrm{C} 9$ \\
\hline B3LYP 6-31G(d) & 109.5531 & 111.326 & 108.0938 & 110.2346 & 110.5034 & 107.1887 & 109.5274 \\
B3LYP 6-31G(d,p) & 109.5531 & 111.326 & 108.0938 & 110.2346 & 110.5034 & 107.1887 & 109.5274 \\
B3LYP 6-311G(d,p) & 109.5531 & 111.326 & 108.0938 & 110.2346 & 110.5034 & 107.1887 & 109.5274 & 110.6744 \\
SCXRD & 109.63 & 111.39 & 108.00 & 110.2 & 110.49 & 107.27 & 109.48 & 110.6744 \\
\hline
\end{tabular}

Table 6

Comparison of selected experimental and calculated torsion angles $\left(^{\circ}\right)$ for $(1)$.

\begin{tabular}{lllllcc}
\hline Functional/Basis set & $\mathrm{O} 5-\mathrm{C} 5-\mathrm{C} 4-\mathrm{O} 4$ & $\mathrm{O} 4-\mathrm{C} 4-\mathrm{C} 3-\mathrm{O} 3$ & $\mathrm{O} 3-\mathrm{C} 3-\mathrm{C} 2-\mathrm{O} 2$ & $\mathrm{C} 2-\mathrm{O} 2-\mathrm{C} 7-\mathrm{C} 8$ & $\mathrm{O} 2-\mathrm{C} 7-\mathrm{C} 8-\mathrm{C} 9$ & $\mathrm{C} 7-\mathrm{C} 8-\mathrm{C} 9-\mathrm{C} 10$ \\
\hline B3LYP 6-31G $(d)$ & 60.40 & -60.7377 & 78.0022 & -117.1225 & -65.6377 & -55.7909 \\
B3LYP 6-31G(d,p) & 60.40 & -60.7377 & 78.0022 & -117.1225 & -65.6377 & -55.7909 \\
B3LYP 6-311G(d,p) & 60.40 & -60.7377 & 78.0022 & -117.1225 & -65.6377 & -55.7909 \\
SCXRD & 60.37 & -60.68 & 77.97 & -116.94 & -65.9 & -55.7 \\
\hline
\end{tabular}

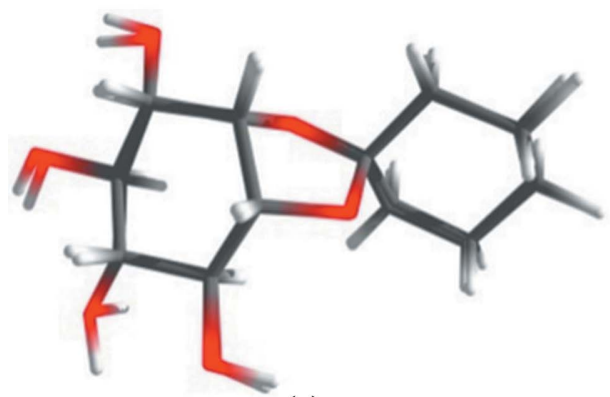

Figure 4

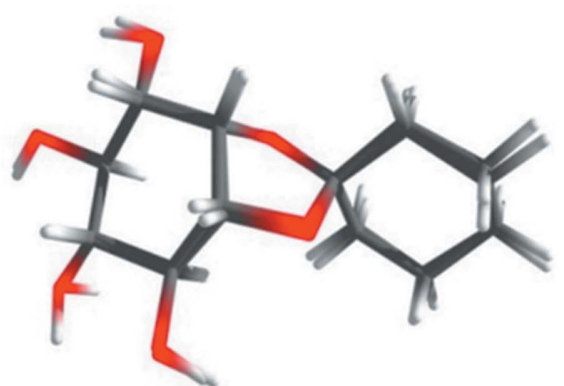

(b)

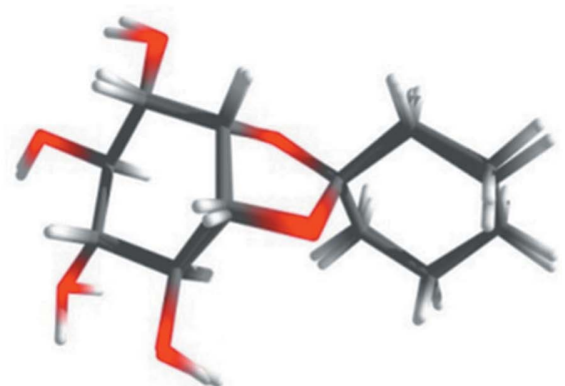

(c)

Structures of (1) overlayed using CHEMCRAFT (http://www.chemcraftprog.com): (a) B3LYP/6-31G(d) (r.m.s. deviation 0.2847); (b) B3LYP/6-31G(d,p) (r.m.s. deviation 0.2839); (c) B3LYP/6-311G(d,p) (r.m.s. deviation 0.2804). 


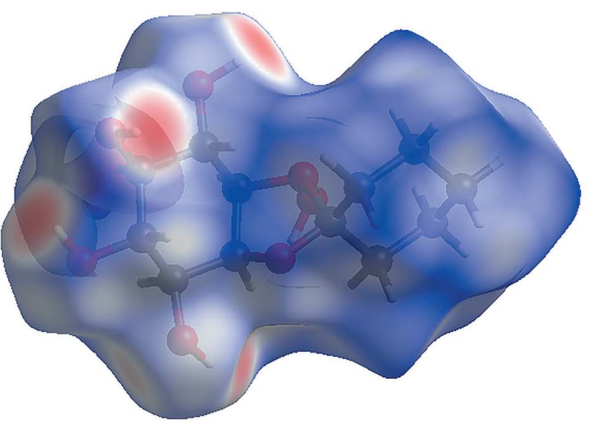

(a)

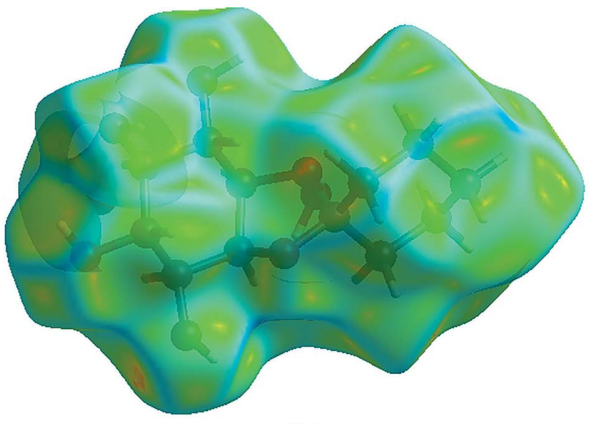

(b)

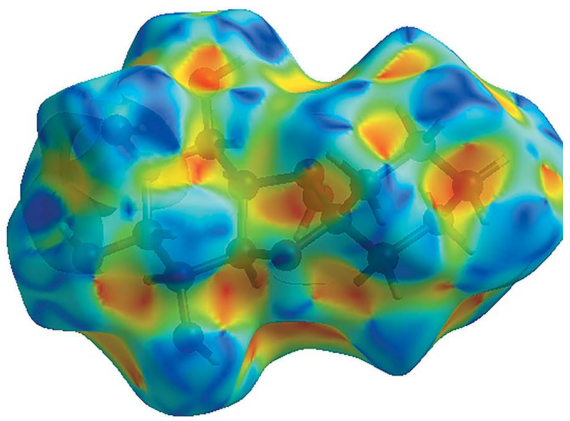

(c)

Figure 5

(b) curvature and (c) shape index.

the form of the molecule (experimental structure: crystalline state; theoretical structure: gas phase). A quantitative comparison between the experimental and calculated optimized geometrical parameters for selected bond lengths, bond angles and torsion angles is given in Tables 4, 5 and 6 . This also indicates the close agreement between the combinations of B3LYP functionals with $6-31 \mathrm{G}(\mathrm{d}), \quad 6-31 \mathrm{G}(\mathrm{d}, \mathrm{p})$ and $6-311 \mathrm{G}(\mathrm{d}, \mathrm{p})$ basis-set calculations and the X-ray crystallographic structure.

\subsection{Hirshfeld surface analysis}

To visualize the intermolecular interactions in (1), the Hirshfeld surface (HS) was mapped with $d_{\text {norm }}$, curvedness and shape index (Fig. 5). In the HS with the $d_{\text {form }}$ (Fig. 5a), the white surface indicates contacts with distances equal to the sum of the van der Waals (vdW) radii, and the red and blue colours indicate distances shorter (in close contact) or longer (distant contact) than the vdW radii, respectively (Venkatesan et al., 2016). Fig. 5(b) demonstrates the curvature of the surface, with flat surfaces in green and curved regions in blue, and is useful for depicting favourable stacking of the molecule in the crystal (Soman et al., 2014). The shape index on the HS is a tool to visualize the $\pi-\pi$ stacking by the presence of adjacent red and blue triangles; Fig. 5(c) clearly suggests that there are no $\pi-\pi$ stacking interactions in (1), since there are no adjacent red and blue triangles (Seth et al., 2011).

Most of the intermolecular interactions (Figs. 6-8) are of the $\mathrm{H} \cdots \mathrm{H}(57.6 \%)$ and $\mathrm{O} \cdots \mathrm{H}(39.6 \%)$ types, with a few of the $\mathrm{O} \cdots \mathrm{O}$ type $(2.8 \%)$. The large number of $\mathrm{H} \cdots \mathrm{H}$ and $\mathrm{O} \cdots \mathrm{H}$ interactions suggests that $\mathrm{vdW}$ interactions and hydrogen bonding play the major roles in the crystal packing (Hathwar

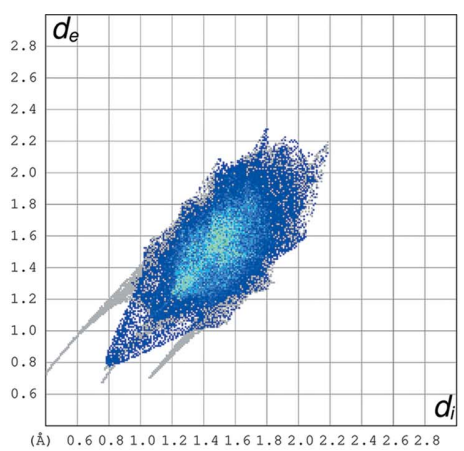

(a)

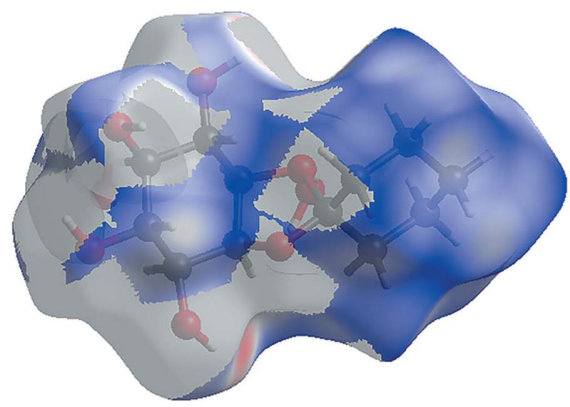

(d)

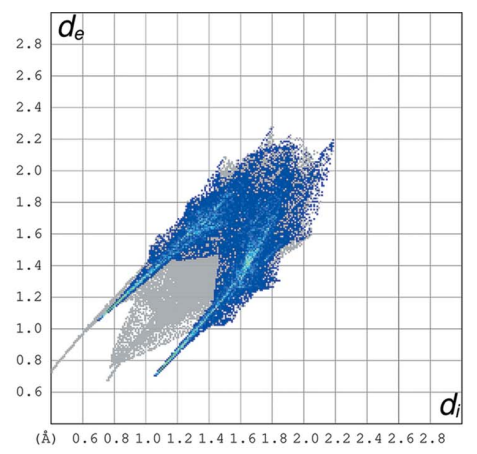

(b)

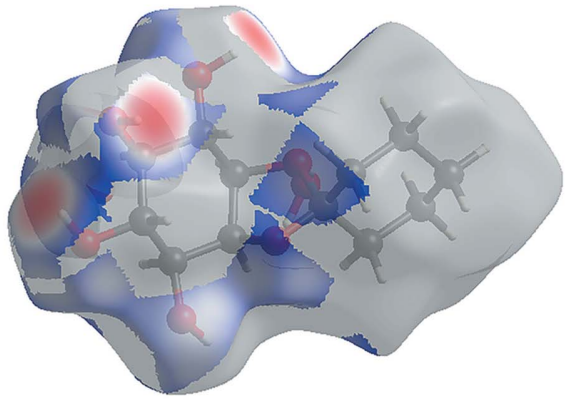

(e)

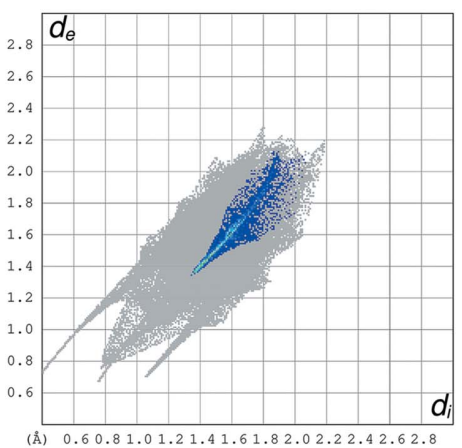

(c)

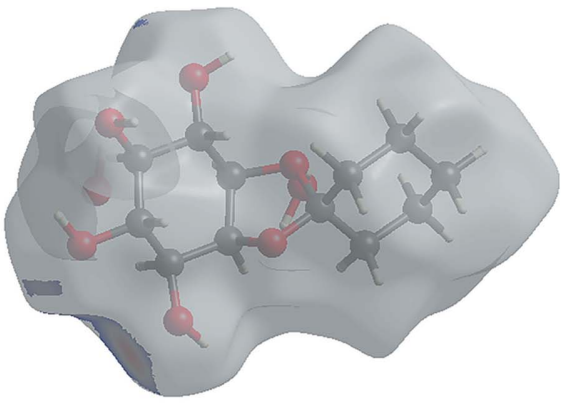

$(f)$

Figure 6

The contribution of different kinds of intermolecular interactions contributing to the total interaction energy in (1). 2D fingerprint plots of (1), with $d_{\mathrm{i}}$ and $d_{\mathrm{e}}$ ranging from 1.0 to $2.8 \AA$ are shown for $(a) \mathrm{H} \cdots \mathrm{H},(b) \mathrm{O} \cdots \mathrm{H}$ and $(c) \mathrm{O} \cdots \mathrm{O}$, and Hirshfeld surface representations with the function $d_{\text {norm }}$ plotted onto the surface are shown for $(d) \mathrm{H} \cdots \mathrm{H},(e) \mathrm{O} \cdots \mathrm{H}$ and $(f) \mathrm{O} \cdots \mathrm{O}$. 


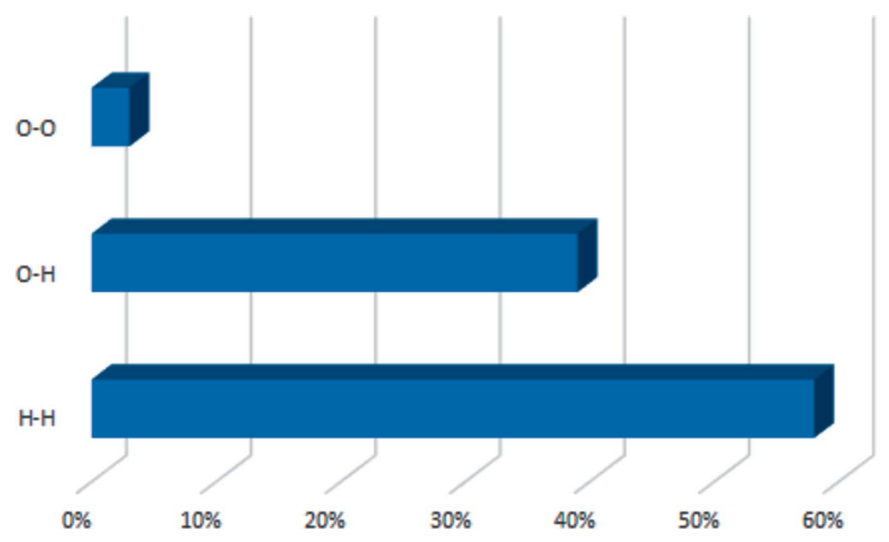

Figure 7

The percentages of the various types of intermolecular interactions in (1).

Table 7

Lattice energy from CLP (in kcal mol${ }^{-1}$ ) for (1).

\begin{tabular}{lccccc}
\hline Compound & $E_{\mathrm{col}}$ & $E_{\mathrm{Pol}}$ & $E_{\text {Disp }}$ & $E_{\text {Rep }}$ & $E_{\text {Tot }}$ \\
\hline$(1)$ & -28.9 & -59.6 & -106.3 & 46.7 & -151.6 \\
\hline
\end{tabular}

et al., 2015). The electrostatic complementarity of (1) is shown in Fig. 9. The blue region indicates the positive electrostatic potential (hydrogen-bond donor), while the red region indicates the negative electrostatic potential (hydrogen-bond acceptors) (Spackman et al., 2008).

\subsection{Lattice-energy calculations using the PIXELC module}

Using the PIXELC software package, the total lattice energy has been calculated for (1) and denotes the different types of energy interactions, such as Coulombic, polarization, dispersion or repulsion components, as shown in Table 7. Dispersion plays a major role in the crystal packing, with a substantial contribution from polarization.

\section{Conclusion}

In the present study, we have reported on the synthesis of 1,2$O$-cyclohexylidene-myo-inositol, (1), with two water molecules in the crystal structure. It is confirmed that the hydroxy groups at positions 4 and 5 are in a trans configuration, and a rationale is suggested for the difficulties in synthesizing 1,2;4,5di- $O$-cyclohexylidene-myo-inositol. The structure determination of (1) revealed the conformational features (equatorial and axial configuration) in the hydrated form of the compound. We also carried out geometry optimizations and frequency analysis of (1) using the GAUSSIAN09 package with B3LYP functionals and three different basis sets. These calculated structures were found to be very similar to that of the experimental structure. To study the intermolecular interactions in the crystal packing, we calculated the Hirshfeld surface analysis with fingerprint plots, and demonstrated that the $\mathrm{O}-\mathrm{H} \cdots \mathrm{O}$ interactions are the major intermolecular interactions. Lattice-energy calculations suggested that

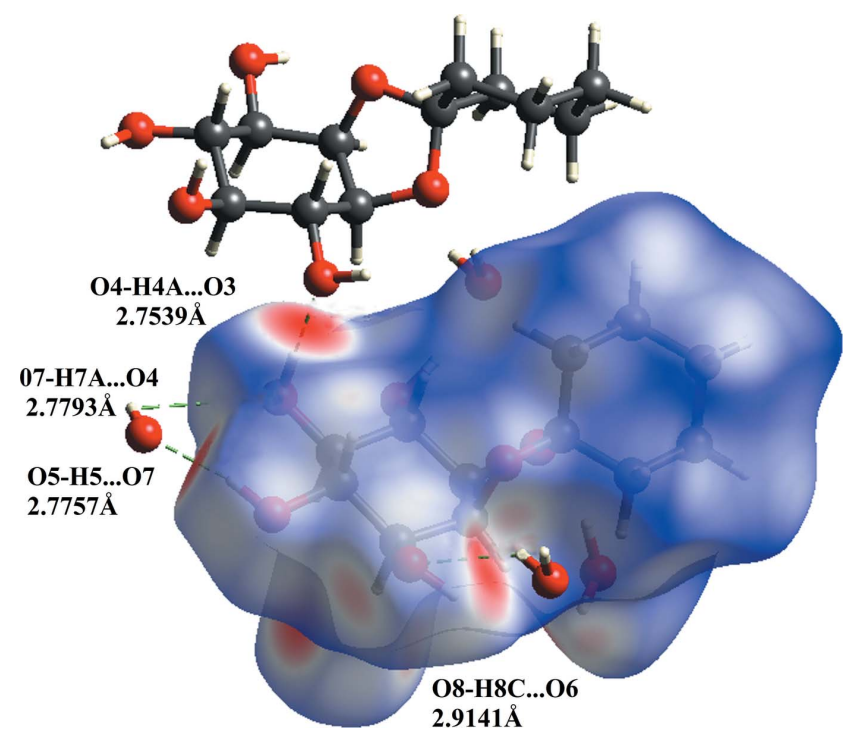

Figure 8

The important intermolecular $\mathrm{O}-\mathrm{H} \cdots \mathrm{O}$ interactions in (1) via Hirshfeld surfaces.

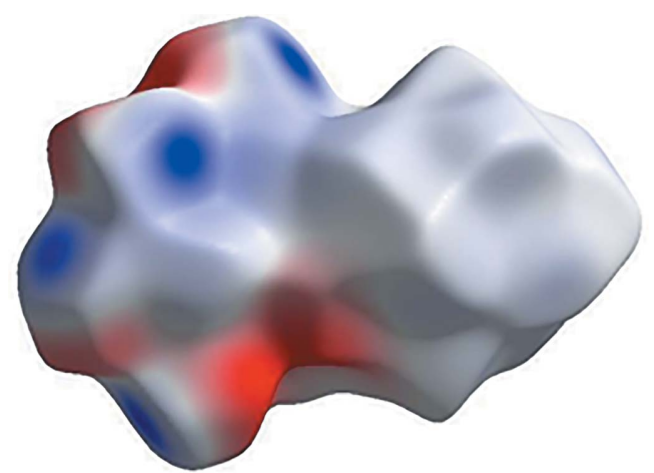

Figure 9

The electrostatic potentials mapped on Hirshfeld surfaces for molecules in (1). The blue region corresponds to positive electrostatic potential and the red region corresponds to negative electrostatic potential.

dispersion is the major contributor to the crystal packing. These insights into the details of the intermolecular interactions and crystal packing will aid in the design and synthesis of new potential anticancer derivatives of myo-inositol.

\section{Acknowledgements}

The authors would like to thank the X-Ray facility at IISER Pune for allowing us to collect the data. GP, KJ and VT thank IITGN for funding. SK is grateful for a Ramanujan Fellowship, DST. PKV thanks the Department of Biotechnology, Government of India, for a Ramalingaswami Re-Entry Fellowship.

\section{References}

Allen, F. H. (2002). Acta Cryst. B58, 380-388.

Allen, F. H. \& Motherwell, W. D. S. (2002). Acta Cryst. B58, 407-422.

Baten, A., Ullah, A., Tomazic, V. J. \& Shamsuddin, A. M. (1989). Carcinogenesis, 10, 1595-1598. 
Becke, A. D. (1993). J. Chem. Phys. 98, 5648-5652.

Berridge, M. J. \& Irvine, R. F. (1989). Nature, 341, 197-205.

Bruker (2008). SADABS. Bruker AXS Inc., Madison, Wisconsin, USA.

Bruker (2009). APEX2. Bruker AXS Inc., Madison, Wisconsin, USA.

Bruker (2012). SAINT-Plus. Bruker AXS Inc., Madison, Wisconsin, USA.

Chen, W., Deng, Z., Chen, K., Dou, D., Song, F., Li, L. \& Xi, Z. (2015). Eur J. Med. Chem. 93, 172-181.

De Camilli, P., Emr, S. D., McPherson, P. S. \& Novick, P. (1996). Science, 271, 1533-1539.

Desiraju, G. R. (1999). The Weak Hydrogen Bond in Structural Chemistry and Biology. Oxford: Oxford University Press/International Union of Crystallography.

Elahi, A. \& Kant, R. (2014). Eur Chem Bull. 3, 619-623.

Farrugia, L. J. (2012). J. Appl. Cryst. 45, 849-854.

Frisch, M. J., et al. (2009). GAUSSIAN09. Gaussian Inc., Wallingford, CT, USA. http://www.gaussian.com.

Gainsford, G. J., Baars, S. M. \& Falshaw, A. (2007). Acta Cryst. C63, o169-o172.

Gavezzotti, A. (2011). New J Chem. 35, 1360-1368.

González-Montiel, S., Baca-Téllez, S., Martínez-Otero, D., ÁlvarezHernández, A. \& Cruz-Borbolla, J. (2015). Mod. Chem. Appl. 3, article No. 154.

Groom, C. R. \& Allen, F. H. (2014). Angew. Chem. Int. Ed. Engl. 53, 662-671.

Guthrie, R. D. \& Johnson, L. F. (1961). J. Chem. Soc. pp. 41664172.

Hathwar, V. R., Sist, M., Jørgensen, M. R. V., Mamakhel, A. H., Wang, X., Hoffmann, C. M., Sugimoto, K., Overgaard, J. \& Iversen, B. B. (2015). IUCrJ, 2, 563-574.

Jayatilaka, D., Grimwood, D. J., Lee, A., Lemay, A., Russel, A. J., Taylor, C., Wolff, S. K., Cassam-Chenai, P. \& Whitton, A. (2005). TONTO. University of Western Australia.

Jiang, C. \& Baker, D. C. (1986). J. Carbohydr. Chem. 5, 615-620.

Kaftory, M., Kapon, M. \& Botoshansky, M. (1994). Chem. Mater. 6, 1245-1249.
Macrae, C. F., Bruno, I. J., Chisholm, J. A., Edgington, P. R., McCabe, P., Pidcock, E., Rodriguez-Monge, L., Taylor, R., van de Streek, J. \& Wood, P. A. (2008). J. Appl. Cryst. 41, 466-470.

McKinnon, J. J., Spackman, M. A. \& Mitchell, A. S. (2004). Acta Cryst. B60, 627-668.

Nkambule, C. M., Kwezi, N. W., Kinfe, H. H., Nokwequ, M. G., Gammon, D. W., Oscarson, S. \& Karlsson, E. (2011). Tetrahedron, 67, 618-623.

Parr, R. R. Y. R. G. (1989). In Density Functional Theory of Atoms and Molecules. New York: Oxford Univeristy Press.

Roy, A., Rahman, M., Das, S., Kundu, D., Kundu, S. K., Majee, A. \& Hajra, A. (2009). Synth. Commun. 39, 590-595.

Schekman, R. \& Orci, L. (1996). Science, 271, 1526-1533.

Seth, S. K., Maity, G. C. \& Kar, T. (2011). J. Mol. Struct. 1000, 120-126.

Shamsuddin, A. M. (1995). J. Nutr. 125, 725S-732S.

Sheldrick, G. M. (2008). Acta Cryst. A64, 112-122.

Soman, R., Sujatha, S. \& Arunkumar, C. (2014). J. Fluorine Chem. 163, 16-22.

Spackman, M. A. \& Jayatilaka, D. (2009). CrystEngComm, 11, 19-32.

Spackman, M. A. \& McKinnon, J. J. (2002). CrystEngComm, 4, 378392.

Spackman, M. A., McKinnon, J. J. \& Jayatilaka, D. (2008). CrystEngComm, 10, 377-388.

Spek, A. L. (2009). Acta Cryst. D65, 148-155.

Suzuki, T., Suzuki, S. T., Yamada, I., Koashi, Y., Yamada, K. \& Chida, N. (2002). J. Org. Chem. 67, 2874-2880.

Tokay, N., Seferoğl, Z., Öğretir, C. \& Ertan, N. (2008). ARKIVOK, 2008, 9-20.

Venkatesan, P., Thamotharan, S., Ilangovan, A., Liang, H. \& Sundius, T. (2016). Spectrochim. Acta Part A, 153, 625-636.

Vucenik, I. \& Shamsuddin, A. M. (2003). J. Nutr. 133, 3778S-3784S.

Watkin, D. M. P. L. \& Prout, C. K. (1993). CAMERON. Chemical Crystallography Laboratory, University of Oxford, England.

Wolff, S. K., Grimwood, D. J., McKinnon, J. J., Turner, M. J., Jayatilaka, D. \& Spackman, M. A. (2012). Crystal Explorer. University of Western Australia.

Yang, G. Y. \& Shamsuddin, A. M. (1995). Anticancer Res. 15, 2479 2487. 


\section{supporting information}

Acta Cryst. (2017). C73, 20-27 [https://doi.org/10.1107/S2053229616018581]

\section{Water-mediated intermolecular interactions in 1,2-O-cyclohexylidene-myo-} inositol: a quantitative analysis

\section{Gayathri Purushothaman, Kapil Juvale, Sivapriya Kirubakaran, Praveen Kumar Vemula and Vijay} Thiruvenkatam

\section{Computing details}

Data collection: APEX2 (Bruker, 2009); cell refinement: APEX2 (Bruker, 2009); data reduction: SAINT-Plus (Bruker, 2012); program(s) used to solve structure: SHELXL97 (Sheldrick, 2008) in WinGX (Farrugia, 2012); program(s) used to refine structure: SHELXL97 (Sheldrick, 2008) in WinGX (Farrugia, 2012); molecular graphics: ORTEP-3 for Windows (Farrugia, 2012), CAMERON (Watkin \& Prout, 1993) and Mercury (Macrae et al., 2008); software used to prepare material for publication: PLATON (Spek, 2009).

1,2-O-Cyclohexylidene-myo-inositol dihydrate

Crystal data

$\mathrm{C}_{12} \mathrm{H}_{20} \mathrm{O}_{6} \cdot 2 \mathrm{H}_{2} \mathrm{O}$

$F(000)=1272$

$M_{r}=296.31$

Monoclinic, $C 2 / c$

Hall symbol: $-\mathrm{C} 2 \mathrm{yc}$

$a=38.459$ (3) $\AA$

$b=8.6208(7) \AA$

$c=8.2420(7) \AA$

$\beta=95.371(2)^{\circ}$

$V=2720.6(4) \AA^{3}$

$D_{\mathrm{x}}=1.447 \mathrm{Mg} \mathrm{m}^{-3}$

Melting point: $454 \mathrm{~K}$

Mo $K \alpha$ radiation, $\lambda=0.71073 \AA$

Cell parameters from 8730 reflections

$\theta=2.4-26.1^{\circ}$

$\mu=0.12 \mathrm{~mm}^{-1}$

$T=298 \mathrm{~K}$

$Z=8$

Block, white

$0.45 \times 0.35 \times 0.35 \mathrm{~mm}$

Data collection

Bruker APEXII CCD

diffractometer

Radiation source: fine-focus sealed X-ray tube $\varphi$ and $\omega$ scans

Absorption correction: multi-scan

(SADABS; Bruker, 2008)

$T_{\min }=0.935, T_{\max }=0.972$

38263 measured reflections

3391 independent reflections

2347 reflections with $I>2 \sigma(I)$

$R_{\text {int }}=0.129$

$\theta_{\text {max }}=28.3^{\circ}, \theta_{\min }=2.1^{\circ}$

$h=-51 \rightarrow 51$

$k=-11 \rightarrow 11$

$l=-11 \rightarrow 10$

\section{1 parameters}

1 restraint

Hydrogen site location: mixed

$\mathrm{H}$ atoms treated by a mixture of independent and constrained refinement

$S=1.24$

3391 reflections 
$w=1 /\left[\sigma^{2}\left(F_{\mathrm{o}}^{2}\right)+(0.0598 P)^{2}+0.8204 P\right]$

where $P=\left(F_{\mathrm{o}}^{2}+2 F_{\mathrm{c}}^{2}\right) / 3$

$(\Delta / \sigma)_{\max }<0.001$

$$
\Delta \rho_{\max }=0.20 \mathrm{e} \AA^{-3}
$$

\section{Special details}

Experimental. The data was collected with the Bruker cryosystem a low-temperature attachment.

Geometry. Bond distances, angles etc. have been calculated using the rounded fractional coordinates. All su's are estimated from the variances of the (full) variance-covariance matrix. The cell esds are taken into account in the estimation of distances, angles and torsion angles

Refinement. Reflections were merged by SHELXL according to the crystal class for the calculation of statistics and refinement.

_reflns_Friedel_fraction is defined as the number of unique Friedel pairs measured divided by the number that would be possible theoretically, ignoring centric projections and systematic absences.

Various restraints, for example riding model, were used on the hydrogen atoms. All hydrogen atom evident from the difference maps. There appears to be disorder among the hydrogen atoms on atoms O5, O6, and the two water molecules O7 and O8. Successive trials with placement and refinement of hydrogen atoms resulted in the model deposited, with only one short $\mathrm{H} \cdots \mathrm{H}$ contact distance.

Fractional atomic coordinates and isotropic or equivalent isotropic displacement parameters $\left(\AA^{2}\right)$

\begin{tabular}{|c|c|c|c|c|}
\hline & $x$ & $y$ & $z$ & $U_{\text {iso }} * / U_{\text {eq }}$ \\
\hline O1 & $0.13181(3)$ & $0.11890(16)$ & $0.82458(16)$ & $0.0139(4)$ \\
\hline $\mathrm{O} 2$ & $0.14165(3)$ & $0.32282(16)$ & $0.65515(16)$ & $0.0138(4)$ \\
\hline $\mathrm{O} 3$ & $0.08365(4)$ & $0.55158(15)$ & $0.70889(16)$ & $0.0160(4)$ \\
\hline $\mathrm{O} 4$ & $0.03829(4)$ & $0.43349(16)$ & $0.93025(16)$ & $0.0144(4)$ \\
\hline O5 & 0.02128 & $0.11220(16)$ & 0.89709 (17) & $0.0170(4)$ \\
\hline O6 & $0.07640(4)$ & $-0.08649(15)$ & $0.81162(17)$ & $0.0157(4)$ \\
\hline $\mathrm{C} 1$ & $0.10407(5)$ & $0.1245(2)$ & $0.6947(2)$ & $0.0120(6)$ \\
\hline $\mathrm{C} 2$ & $0.10464(5)$ & $0.2942(2)$ & $0.6505(2)$ & $0.0121(6)$ \\
\hline $\mathrm{C} 3$ & $0.08820(5)$ & $0.3984(2)$ & $0.7725(2)$ & $0.0117(6)$ \\
\hline $\mathrm{C} 4$ & $0.05265(5)$ & $0.3387(2)$ & $0.8116(2)$ & $0.0116(6)$ \\
\hline $\mathrm{C} 5$ & $0.05495(5)$ & $0.1712(2)$ & $0.8713(2)$ & $0.0117(6)$ \\
\hline C6 & $0.07008(5)$ & $0.0650(2)$ & $0.7490(2)$ & $0.0117(6)$ \\
\hline $\mathrm{C} 7$ & $0.15910(5)$ & $0.2109(2)$ & $0.7687(2)$ & $0.0146(6)$ \\
\hline $\mathrm{O} 7$ & $0.02069(4)$ & $0.25520(17)$ & $0.39098(17)$ & $0.0170(5)$ \\
\hline $\mathrm{C} 8$ & $0.17810(6)$ & $0.2966(3)$ & 0.9113 & $0.0191(7)$ \\
\hline C9 & $0.20799(6)$ & $0.3936(3)$ & 0.8548 & $0.0254(7)$ \\
\hline $\mathrm{C} 10$ & $0.23303(6)$ & $0.2941(3)$ & 0.7669 & $0.0292(8)$ \\
\hline $\mathrm{C} 11$ & $0.21388(6)$ & $0.2082(3)$ & $0.6237(3)$ & $0.0233(7)$ \\
\hline $\mathrm{C} 12$ & $0.18374(6)$ & $0.1127(3)$ & 0.6789 & $0.0185(6)$ \\
\hline O8 & $0.14014(5)$ & $0.2676(2)$ & $0.3013(2)$ & $0.0245(6)$ \\
\hline H1 & $0.1103(6)$ & $0.058(2)$ & $0.609(3)$ & $0.015(6)^{*}$ \\
\hline $\mathrm{H} 2$ & $0.0948(6)$ & $0.321(3)$ & $0.541(3)$ & $0.019(6)^{*}$ \\
\hline H3 & $0.1049(6)$ & $0.400(3)$ & $0.878(3)$ & $0.022(6)^{*}$ \\
\hline $\mathrm{H} 3 \mathrm{~A}$ & 0.10229 & 0.60178 & 0.72855 & $0.0240^{*}$ \\
\hline $\mathrm{H} 4$ & $0.0361(6)$ & $0.343(3)$ & $0.711(3)$ & $0.015(5)^{*}$ \\
\hline $\mathrm{H} 4 \mathrm{~A}$ & 0.05188 & 0.43435 & 1.01620 & $0.0216^{*}$ \\
\hline H5 & 0.01059 & 0.17741 & 0.94958 & $0.0254 *$ \\
\hline H5A & $0.0696(5)$ & $0.172(2)$ & $0.976(3)$ & $0.014(5)^{*}$ \\
\hline
\end{tabular}




$\begin{array}{lllll}\text { H6 } & 0.0517(5) & 0.058(2) & 0.648(2) & 0.007(5)^{*} \\ \text { H6A } & 0.08822 & -0.13656 & 0.74875 & 0.0235^{*} \\ \text { H8A } & 0.1883(6) & 0.210(3) & 0.989(3) & 0.021(6)^{*} \\ \text { H8B } & 0.1612(6) & 0.365(3) & 0.963(3) & 0.016(6)^{*} \\ \text { H9A } & 0.2201(7) & 0.445(3) & 0.951(3) & 0.030(7)^{*} \\ \text { H9B } & 0.1967(6) & 0.477(3) & 0.790(3) & 0.027(7)^{*} \\ \text { H10A } & 0.2438(7) & 0.212(3) & 0.846(3) & 0.034(7)^{*} \\ \text { H10B } & 0.2503(7) & 0.351(3) & 0.732(3) & 0.032(7)^{*} \\ \text { H11A } & 0.2294(7) & 0.141(3) & 0.569(3) & 0.033(7)^{*} \\ \text { H11B } & 0.2042(7) & 0.284(3) & 0.538(3) & 0.042(8)^{*} \\ \text { H12A } & 0.1929(5) & 0.025(3) & 0.754(2) & 0.011(5)^{*} \\ \text { H12B } & 0.1706(6) & 0.064(3) & 0.596(3) & 0.026(7)^{*} \\ \text { H7A } & 0.0239(7) & 0.351(2) & 0.406(3) & 0.033(7)^{*} \\ \text { H8C } & 0.1319(8) & 0.188(4) & 0.306(4) & 0.056(12)^{*} \\ \text { H8D } & 0.1447(8) & 0.300(4) & 0.406(4) & 0.061(10)^{*} \\ \end{array}$

Atomic displacement parameters $\left(\AA^{2}\right)$

\begin{tabular}{lllllll}
\hline & $U^{11}$ & $U^{22}$ & $U^{33}$ & $U^{12}$ & $U^{13}$ & $U^{23}$ \\
\hline O1 & $0.0107(7)$ & $0.0172(8)$ & $0.0137(7)$ & $-0.0012(6)$ & $-0.0001(5)$ & $0.0041(6)$ \\
O2 & $0.0114(7)$ & $0.0164(7)$ & $0.0138(7)$ & $-0.0001(6)$ & $0.0023(5)$ & $0.0032(6)$ \\
O3 & $0.0185(8)$ & $0.0104(7)$ & $0.0186(7)$ & $-0.0026(6)$ & $-0.0007(6)$ & $0.0038(6)$ \\
O4 & $0.0183(8)$ & $0.0138(7)$ & $0.0115(7)$ & $0.0020(6)$ & $0.0031(6)$ & $-0.0028(5)$ \\
O5 & $0.0145(8)$ & $0.0138(7)$ & $0.0242(8)$ & $0.0004(6)$ & $0.0104(6)$ & $-0.0027(6)$ \\
O6 & $0.0175(8)$ & $0.0093(7)$ & $0.0208(8)$ & $0.0036(6)$ & $0.0048(6)$ & $-0.0004(6)$ \\
C1 & $0.0113(10)$ & $0.0143(10)$ & $0.0102(9)$ & $0.0022(8)$ & $0.0006(8)$ & $-0.0001(8)$ \\
C2 & $0.0112(10)$ & $0.0143(10)$ & $0.0111(10)$ & $-0.0012(8)$ & $0.0021(8)$ & $0.0005(8)$ \\
C3 & $0.0145(10)$ & $0.0089(10)$ & $0.0116(9)$ & $0.0006(8)$ & $0.0001(8)$ & $0.0019(8)$ \\
C4 & $0.0137(10)$ & $0.0120(10)$ & $0.0091(9)$ & $0.0007(8)$ & $0.0019(8)$ & $-0.0020(8)$ \\
C5 & $0.0112(10)$ & $0.0132(10)$ & $0.0106(9)$ & $-0.0024(8)$ & $0.0013(8)$ & $0.0000(8)$ \\
C6 & $0.0136(10)$ & $0.0091(10)$ & $0.0123(9)$ & $0.0000(8)$ & $0.0006(8)$ & $0.0012(8)$ \\
C7 & $0.0123(10)$ & $0.0169(11)$ & $0.0146(10)$ & $-0.0006(8)$ & $0.0009(8)$ & $0.0044(8)$ \\
O7 & $0.0210(8)$ & $0.0113(8)$ & $0.0189(8)$ & $-0.0008(6)$ & $0.0028(6)$ & $-0.0007(6)$ \\
C8 & $0.0157(11)$ & $0.0223(12)$ & $0.0192(11)$ & $-0.0014(9)$ & $0.0008(9)$ & $-0.0008(9)$ \\
C9 & $0.0203(12)$ & $0.0272(13)$ & $0.0278(12)$ & $-0.0076(11)$ & $-0.0020(10)$ & $-0.0001(11)$ \\
C10 & $0.0148(12)$ & $0.0387(16)$ & $0.0343(14)$ & $-0.0084(11)$ & $0.0028(10)$ & $0.0033(12)$ \\
C11 & $0.0168(12)$ & $0.0270(13)$ & $0.0271(12)$ & $0.0012(10)$ & $0.0073(10)$ & $0.0016(10)$ \\
C12 & $0.0162(11)$ & $0.0177(11)$ & $0.0217(11)$ & $0.0002(9)$ & $0.0029(9)$ & $-0.0010(9)$ \\
O8 & $0.0274(10)$ & $0.0224(10)$ & $0.0242(9)$ & $0.0018(8)$ & $0.0056(7)$ & $0.0020(8)$ \\
& & & & & & \\
\hline
\end{tabular}

Geometric parameters $\left(\AA,{ }^{o}\right)$

\begin{tabular}{llll}
\hline $\mathrm{O} 1-\mathrm{C} 1$ & $1.440(2)$ & $\mathrm{C} 10-\mathrm{C} 11$ & $1.524(3)$ \\
$\mathrm{O} 1-\mathrm{C} 7$ & $1.426(2)$ & $\mathrm{C} 11-\mathrm{C} 12$ & $1.526(3)$ \\
$\mathrm{O} 2-\mathrm{C} 2$ & $1.442(2)$ & $\mathrm{C} 1-\mathrm{H} 1$ & $0.96(2)$ \\
$\mathrm{O} 2-\mathrm{C} 7$ & $1.463(2)$ & $\mathrm{C} 2-\mathrm{H} 2$ & $0.97(2)$ \\
$\mathrm{O} 3-\mathrm{C} 3$ & $1.426(2)$ & $\mathrm{C} 3-\mathrm{H} 3$ & $1.03(2)$ \\
$\mathrm{O} 4-\mathrm{C} 4$ & $1.425(2)$ & $\mathrm{C} 4-\mathrm{H} 4$ & $1.00(2)$
\end{tabular}




\begin{tabular}{|c|c|c|c|}
\hline $\mathrm{O} 5-\mathrm{C} 5$ & $1.426(2)$ & $\mathrm{C} 5-\mathrm{H} 5 \mathrm{~A}$ & $0.99(2)$ \\
\hline $\mathrm{O} 6-\mathrm{C} 6$ & $1.417(2)$ & C6-H6 & $1.042(17)$ \\
\hline $\mathrm{O} 3-\mathrm{H} 3 \mathrm{~A}$ & 0.8400 & $\mathrm{O} 7-\mathrm{H} 7 \mathrm{~A}$ & $0.843(18)$ \\
\hline $\mathrm{O} 4-\mathrm{H} 4 \mathrm{~A}$ & 0.8400 & $\mathrm{C} 8-\mathrm{H} 8 \mathrm{~B}$ & $1.00(2)$ \\
\hline $\mathrm{O} 5-\mathrm{H} 5$ & 0.8400 & $\mathrm{C} 8-\mathrm{H} 8 \mathrm{~A}$ & $1.04(3)$ \\
\hline O6-H6A & 0.8400 & $\mathrm{C} 9-\mathrm{H} 9 \mathrm{~A}$ & $0.99(3)$ \\
\hline $\mathrm{C} 1-\mathrm{C} 6$ & $1.511(3)$ & С9-Н9B & $0.97(3)$ \\
\hline $\mathrm{C} 1-\mathrm{C} 2$ & $1.508(2)$ & $\mathrm{C} 10-\mathrm{H} 10 \mathrm{~B}$ & $0.90(3)$ \\
\hline $\mathrm{C} 2-\mathrm{C} 3$ & $1.529(2)$ & $\mathrm{C} 10-\mathrm{H} 10 \mathrm{~A}$ & $1.02(3)$ \\
\hline $\mathrm{C} 3-\mathrm{C} 4$ & $1.523(3)$ & $\mathrm{C} 11-\mathrm{H} 11 \mathrm{~A}$ & $0.97(3)$ \\
\hline $\mathrm{C} 4-\mathrm{C} 5$ & $1.525(2)$ & C11-H11B & $1.01(3)$ \\
\hline $\mathrm{C} 5-\mathrm{C} 6$ & $1.517(2)$ & $\mathrm{C} 12-\mathrm{H} 12 \mathrm{~A}$ & $1.02(2)$ \\
\hline $\mathrm{C} 7-\mathrm{C} 8$ & $1.517(3)$ & $\mathrm{C} 12-\mathrm{H} 12 \mathrm{~B}$ & $0.91(2)$ \\
\hline $\mathrm{C} 7-\mathrm{C} 12$ & $1.515(3)$ & $\mathrm{O} 8-\mathrm{H} 8 \mathrm{C}$ & $0.76(3)$ \\
\hline $\mathrm{C} 8-\mathrm{C} 9$ & $1.529(3)$ & $\mathrm{O} 8-\mathrm{H} 8 \mathrm{D}$ & $0.91(3)$ \\
\hline $\mathrm{C} 9-\mathrm{C} 10$ & $1.523(3)$ & & \\
\hline $\mathrm{C} 1-\mathrm{O} 1-\mathrm{C} 7$ & $104.94(13)$ & $\mathrm{C} 3-\mathrm{C} 2-\mathrm{H} 2$ & $108.8(15)$ \\
\hline $\mathrm{C} 2-\mathrm{O} 2-\mathrm{C} 7$ & $107.27(13)$ & $\mathrm{O} 3-\mathrm{C} 3-\mathrm{H} 3$ & $110.1(14)$ \\
\hline $\mathrm{C} 3-\mathrm{O} 3-\mathrm{H} 3 \mathrm{~A}$ & 109.00 & $\mathrm{C} 2-\mathrm{C} 3-\mathrm{H} 3$ & $107.4(14)$ \\
\hline $\mathrm{C} 4-\mathrm{O} 4-\mathrm{H} 4 \mathrm{~A}$ & 109.00 & $\mathrm{C} 4-\mathrm{C} 3-\mathrm{H} 3$ & $109.1(13)$ \\
\hline $\mathrm{C} 5-\mathrm{O} 5-\mathrm{H} 5$ & 109.00 & $\mathrm{O} 4-\mathrm{C} 4-\mathrm{H} 4$ & $106.9(14)$ \\
\hline $\mathrm{C} 6-\mathrm{O} 6-\mathrm{H} 6 \mathrm{~A}$ & 109.00 & $\mathrm{C} 3-\mathrm{C} 4-\mathrm{H} 4$ & $109.1(14)$ \\
\hline $\mathrm{O} 1-\mathrm{C} 1-\mathrm{C} 6$ & $111.71(13)$ & $\mathrm{C} 5-\mathrm{C} 4-\mathrm{H} 4$ & $108.5(15)$ \\
\hline $\mathrm{C} 2-\mathrm{C} 1-\mathrm{C} 6$ & $115.69(15)$ & $\mathrm{O} 5-\mathrm{C} 5-\mathrm{H} 5 \mathrm{~A}$ & $109.0(12)$ \\
\hline $\mathrm{O} 1-\mathrm{C} 1-\mathrm{C} 2$ & $100.70(14)$ & $\mathrm{C} 4-\mathrm{C} 5-\mathrm{H} 5 \mathrm{~A}$ & $106.7(10)$ \\
\hline $\mathrm{O} 2-\mathrm{C} 2-\mathrm{C} 3$ & $110.49(14)$ & $\mathrm{C} 6-\mathrm{C} 5-\mathrm{H} 5 \mathrm{~A}$ & $111.3(11)$ \\
\hline $\mathrm{C} 1-\mathrm{C} 2-\mathrm{C} 3$ & $113.26(14)$ & $\mathrm{O} 6-\mathrm{C} 6-\mathrm{H} 6$ & $108.5(10)$ \\
\hline $\mathrm{O} 2-\mathrm{C} 2-\mathrm{C} 1$ & $101.32(14)$ & $\mathrm{C} 1-\mathrm{C} 6-\mathrm{H} 6$ & $108.9(10)$ \\
\hline $\mathrm{O} 3-\mathrm{C} 3-\mathrm{C} 2$ & $110.28(14)$ & $\mathrm{C} 5-\mathrm{C} 6-\mathrm{H} 6$ & $107.0(10)$ \\
\hline $\mathrm{O} 3-\mathrm{C} 3-\mathrm{C} 4$ & $108.00(15)$ & $\mathrm{C} 7-\mathrm{C} 8-\mathrm{H} 8 \mathrm{~A}$ & $104.8(14)$ \\
\hline $\mathrm{C} 2-\mathrm{C} 3-\mathrm{C} 4$ & $112.04(14)$ & $\mathrm{C} 7-\mathrm{C} 8-\mathrm{H} 8 \mathrm{~B}$ & $109.4(14)$ \\
\hline $\mathrm{O} 4-\mathrm{C} 4-\mathrm{C} 3$ & $111.39(14)$ & $\mathrm{C} 9-\mathrm{C} 8-\mathrm{H} 8 \mathrm{~A}$ & $109.3(13)$ \\
\hline $\mathrm{C} 3-\mathrm{C} 4-\mathrm{C} 5$ & $111.22(15)$ & $\mathrm{C} 9-\mathrm{C} 8-\mathrm{H} 8 \mathrm{~B}$ & $110.1(14)$ \\
\hline $\mathrm{O} 4-\mathrm{C} 4-\mathrm{C} 5$ & $109.63(14)$ & $\mathrm{H} 8 \mathrm{~A}-\mathrm{C} 8-\mathrm{H} 8 \mathrm{~B}$ & $113(2)$ \\
\hline $\mathrm{O} 5-\mathrm{C} 5-\mathrm{C} 4$ & $111.09(15)$ & $\mathrm{C} 8-\mathrm{C} 9-\mathrm{H} 9 \mathrm{~A}$ & $108.2(15)$ \\
\hline $\mathrm{O} 5-\mathrm{C} 5-\mathrm{C} 6$ & $107.09(14)$ & $\mathrm{C} 8-\mathrm{C} 9-\mathrm{H} 9 \mathrm{~B}$ & $105.2(14)$ \\
\hline $\mathrm{C} 4-\mathrm{C} 5-\mathrm{C} 6$ & $111.79(14)$ & $\mathrm{C} 10-\mathrm{C} 9-\mathrm{H} 9 \mathrm{~A}$ & $111.3(15)$ \\
\hline $\mathrm{C} 1-\mathrm{C} 6-\mathrm{C} 5$ & $112.84(15)$ & $\mathrm{C} 10-\mathrm{C} 9-\mathrm{H} 9 \mathrm{~B}$ & $115.1(15)$ \\
\hline $\mathrm{O} 6-\mathrm{C} 6-\mathrm{C} 1$ & $107.29(15)$ & $\mathrm{H} 9 \mathrm{~A}-\mathrm{C} 9-\mathrm{H} 9 \mathrm{~B}$ & $105(2)$ \\
\hline $\mathrm{O} 6-\mathrm{C} 6-\mathrm{C} 5$ & $112.18(14)$ & $\mathrm{C} 9-\mathrm{C} 10-\mathrm{H} 10 \mathrm{~A}$ & 108.8 \\
\hline $\mathrm{O} 1-\mathrm{C} 7-\mathrm{C} 8$ & $109.66(15)$ & $\mathrm{C} 9-\mathrm{C} 10-\mathrm{H} 10 \mathrm{~B}$ & $111.5(17)$ \\
\hline $\mathrm{O} 1-\mathrm{C} 7-\mathrm{C} 12$ & $111.11(16)$ & $\mathrm{C} 11-\mathrm{C} 10-\mathrm{H} 10 \mathrm{~A}$ & $107.2(14)$ \\
\hline $\mathrm{O} 2-\mathrm{C} 7-\mathrm{C} 8$ & $109.48(15)$ & $\mathrm{C} 11-\mathrm{C} 10-\mathrm{H} 10 \mathrm{~B}$ & $109.7(16)$ \\
\hline $\mathrm{O} 1-\mathrm{C} 7-\mathrm{O} 2$ & $105.43(14)$ & $\mathrm{H} 10 \mathrm{~A}-\mathrm{C} 10-\mathrm{H} 10 \mathrm{~B}$ & $108(2)$ \\
\hline $\mathrm{O} 2-\mathrm{C} 7-\mathrm{C} 12$ & $109.06(15)$ & $\mathrm{C} 10-\mathrm{C} 11-\mathrm{H} 11 \mathrm{~A}$ & $112.1(15)$ \\
\hline $\mathrm{C} 8-\mathrm{C} 7-\mathrm{C} 12$ & $111.89(18)$ & $\mathrm{C} 10-\mathrm{C} 11-\mathrm{H} 11 \mathrm{~B}$ & $110.4(15)$ \\
\hline $\mathrm{C} 7-\mathrm{C} 8-\mathrm{C} 9$ & $110.60(19)$ & $\mathrm{C} 12-\mathrm{C} 11-\mathrm{H} 11 \mathrm{~A}$ & $109.5(16)$ \\
\hline
\end{tabular}




$$
\begin{aligned}
& \mathrm{C} 8-\mathrm{C} 9-\mathrm{C} 10 \\
& \mathrm{C} 9-\mathrm{C} 10-\mathrm{C} 11 \\
& \mathrm{C} 10-\mathrm{C} 11-\mathrm{C} 12 \\
& \mathrm{C} 7-\mathrm{C} 12-\mathrm{C} 11 \\
& \mathrm{O} 1-\mathrm{C} 1-\mathrm{H} 1 \\
& \mathrm{C} 2-\mathrm{C} 1-\mathrm{H} 1 \\
& \mathrm{C} 6-\mathrm{C} 1-\mathrm{H} 1 \\
& \mathrm{O} 2-\mathrm{C} 2-\mathrm{H} 2 \\
& \mathrm{C} 1-\mathrm{C} 2-\mathrm{H} 2 \\
& \mathrm{C} 7-\mathrm{O} 1-\mathrm{C} 1-\mathrm{C} 2 \\
& \mathrm{C} 7-\mathrm{O} 1-\mathrm{C} 1-\mathrm{C} 6 \\
& \mathrm{C} 1-\mathrm{O} 1-\mathrm{C} 7-\mathrm{C} 12 \\
& \mathrm{C} 1-\mathrm{O} 1-\mathrm{C} 7-\mathrm{O} 2 \\
& \mathrm{C} 1-\mathrm{O} 1-\mathrm{C} 7-\mathrm{C} 8 \\
& \mathrm{C} 2-\mathrm{O} 2-\mathrm{C} 7-\mathrm{C} 12 \\
& \mathrm{C} 7-\mathrm{O} 2-\mathrm{C} 2-\mathrm{C} 1 \\
& \mathrm{C} 7-\mathrm{O} 2-\mathrm{C} 2-\mathrm{C} 3 \\
& \mathrm{C} 2-\mathrm{O} 2-\mathrm{C} 7-\mathrm{O} 1 \\
& \mathrm{C} 2-\mathrm{O} 2-\mathrm{C} 7-\mathrm{C} 8 \\
& \mathrm{C} 6-\mathrm{C} 1-\mathrm{C} 2-\mathrm{C} 3 \\
& \mathrm{C} 6-\mathrm{C} 1-\mathrm{C} 2-\mathrm{O} 2 \\
& \mathrm{C} 2-\mathrm{C} 1-\mathrm{C} 6-\mathrm{O} 6 \\
& \mathrm{O} 1-\mathrm{C} 1-\mathrm{C} 6-\mathrm{O} 6 \\
& \mathrm{O} 1-\mathrm{C} 1-\mathrm{C} 6-\mathrm{C} 5 \\
& \mathrm{O} 1-\mathrm{C} 1-\mathrm{C} 2-\mathrm{O} 2 \\
& \mathrm{C} 2-\mathrm{C} 1-\mathrm{C} 6-\mathrm{C} 5 \\
& \mathrm{O} 1-\mathrm{C} 1-\mathrm{C} 2-\mathrm{C} 3 \\
& \mathrm{O} 2-\mathrm{C} 2-\mathrm{C} 3-\mathrm{O} 3 \\
& \mathrm{C} 1-\mathrm{C} 2-\mathrm{C} 3-\mathrm{O} 3 \\
& \mathrm{C} 1-\mathrm{C} 2-\mathrm{C} 3-\mathrm{C} 4 \\
& \mathrm{O} 2-\mathrm{C} 2-\mathrm{C} 3-\mathrm{C} 4
\end{aligned}
$$

$111.3(2)$

$111.16(19)$

$110.9(2)$

$111.8(2)$

$108.0(14)$

$113.1(12)$

$107.4(13)$

$106.3(14)$

$116.2(15)$

$-43.11(16)$

$-166.48(14)$

$-91.05(17)$

$26.96(16)$

$144.73(16)$

$120.33(16)$

$-26.72(16)$

$93.59(15)$

$0.95(17)$

$-116.94(16)$

44.6 (2)

$162.97(14)$

$-169.97(14)$

$-55.56(18)$

$68.50(18)$

$42.40(15)$

$-45.9(2)$

$-75.94(18)$

$77.97(18)$

$-169.16(15)$

$-48.8(2)$

$-161.70(14)$

$$
\begin{aligned}
& \text { C12-C11-H11B } \\
& \text { H11 - } 11-\mathrm{H} 11 \mathrm{~B} \\
& \text { C7-C12-H12A } \\
& \text { C7-C12-H12B } \\
& \text { C11-C12-H12A } \\
& \text { C11-C12-H12B } \\
& \text { H12A-C12-H12B } \\
& \text { H8C-O8-H8D }
\end{aligned}
$$

$108.5(15)$

105 (2)

$108.3(11)$

$107.2(15)$

$110.6(11)$

$114.1(16)$

$104(2)$

$106(3)$

$55.05(18)$

$177.68(14)$

$-60.68(17)$

$176.70(13)$

$60.37(18)$

$-56.44(19)$

$179.93(15)$

$-176.00(13)$

$51.3(2)$

$-65.51(18)$

$173.16(14)$

$172.60(15)$

$178.85(17)$

$-65.9(2)$

$55.1(2)$

$-177.88(17)$

$66.3(2)$

$-54.9(2)$

$-55.7(3)$

$56.1(3)$

$-55.1(3)$

$54.5(3)$

Hydrogen-bond geometry $\left(\AA,{ }^{\circ}\right)$

\begin{tabular}{lllll}
\hline$D-\mathrm{H} \cdots A$ & $D-\mathrm{H}$ & $\mathrm{H} \cdots A$ & $D \cdots A$ & $D-\mathrm{H} \cdots A$ \\
\hline $\mathrm{O} 3-\mathrm{H} 3 A \cdots \mathrm{O} 8^{\mathrm{i}}$ & 0.84 & 1.89 & $2.724(2)$ & 170 \\
$\mathrm{O} 4-\mathrm{H} 4 A \cdots 3^{\mathrm{i}}$ & 0.84 & 1.91 & $2.754(2)$ & 177 \\
$\mathrm{O} 5-\mathrm{H} 5 \cdots \mathrm{O} 4$ & 0.84 & 2.46 & $2.853(2)$ & 109 \\
$\mathrm{O} 5-\mathrm{H} 5 \cdots \mathrm{O} 7^{\mathrm{ii}}$ & 0.84 & 1.98 & $2.776(2)$ & 158 \\
$\mathrm{O} 6-\mathrm{H} 6 A \cdots \mathrm{O} 8^{\mathrm{iii}}$ & 0.84 & 2.30 & $2.914(2)$ & 130 \\
$\mathrm{O} 7-\mathrm{H} 7 A \cdots \mathrm{O} 4^{\text {iv }}$ & $0.843(18)$ & $1.944(18)$ & $2.779(2)$ & $171(3)$ \\
$\mathrm{O} 8-\mathrm{H} 8 C \cdots \mathrm{O} 66^{v}$ & $0.76(3)$ & $2.31(3)$ & $2.914(2)$ & $137(3)$ \\
$\mathrm{O} 8-\mathrm{H} 8 D \cdots \mathrm{O} 2$ & $0.91(3)$ & $2.08(3)$ & $2.950(3)$ & $161(3)$ \\
\hline
\end{tabular}

Symmetry codes: (i) $x,-y+1, z+1 / 2$; (ii) $-x, y,-z+3 / 2$; (iii) $x,-y, z+1 / 2$; (iv) $x,-y+1, z-1 / 2$; (v) $x,-y, z-1 / 2$. 